\title{
Psikologi Tokoh dalam Novel Pulang Karya Leila S. Chudori (Kajian Psikoanalisis Sigmund Freud)
}

\author{
Fauzi Rahman ${ }^{1 *}$ \\ ${ }^{* 1}$ Universitas Indraprasta PGRI, Jakarta, \\ Indonesia \\ *email: fauzierachman20@yahoo.com
}

Received: 29 Maret 2021

Accepted: 31 Maret 2021

Published: 31 Maret 2021

doi: $10.22236 /$ imajeri.v3i2.6718

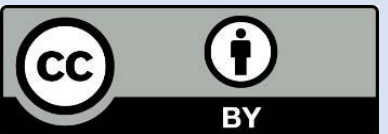

(C) 2021 Oleh authors. Lisensi Imajeri: Jurnal Pendidikan Bahasa dan Sastra Indonesia, Uhamka, Jakarta. Artikel ini bersifat open access yang didistribusikan di bawah syarat dan ketentuan Creative Commons Attribution (CC-BY) license.

(http://creativecommons.org/licenses/by/4.0/).

\begin{abstract}
Abstrak
Novel Pulang dinilai memiliki kekuatan yang menggabungkan cuplikan-cuplikan peristiwa tentang kehidupan orang eksil, yaitu orang-orang Indonesia yang tidak bisa pulang ke tanah air karena situasi politik pada tahun 1965. Leila S Chudori menceritakan kehidupan berbagai tokoh dalam Pulang dengan sangat menarik dan detail. Oleh karena itu, penelitian ini bertujuan untuk mengetahui psikologi tokoh dalam novel Pulang melalui analisis psikologis tokoh berdasarkan struktur kepribadian Freud yang terdiri atas id, ego, dan superego. Hasil yang dicapai dari penelitian ini yaitu bahwa Dimas Suryo lebih banyak memunculkan sifat ego karena dari 35 paragraf dalam 4 episode yang dibahas, muncul 15 paragraf yang menyatakan sifat ego. Selanjutnya, Tokoh Lintang Utara lebih banyak memunculkan sifat id karena dari 35 paragraf dalam 4 episode yang dibahas, muncul 13 paragraf yang menunjukkan sifat id. Tokoh terakhir, Segara Alam lebih banyak memunculkan sifat ego karena dari 22 paragraf dalam 2 episode yang dibahas, muncul 10 paragraf yang menunjukkan sifat ego.
\end{abstract}

Kata kunci: Psikologi sastra, tokoh, novel Pulang, Sigmund Freud

\section{Abstract}

The Pulang was considered to have the power of combining snippets of events about the lives of exiles, namely Indonesians who could not return to their homeland due to the political situation in 1965. Leila S Chudori tells the lives of various characters in Pulang in a very interesting and detailed manner. Therefore, this study aims to determine the psychology of the characters in Pulang through psychological analysis of the characters based on Freud's personality structure consisting of $i d$, ego, and superego. The results achieved from this research are that Dimas Suryo is more likely to bring out ego traits because from the 35 paragraphs in the 4 episodes discussed, 15 paragraphs appear stating the nature of the ego. Furthermore, the Lintang Utara character shows more of the id characteristic because of the 35 paragraphs in the 4 episodes discussed, 13 paragraphs show the character of the id. The last character, Segara Alam shows more ego characteristics because of the 22 paragraphs in the 2 episodes discussed, 10 paragraphs appear showing the nature of the ego.

Keywords: Literary psychology, the main character, the novel Pulang, Sigmund Freud 


\section{PENDAHULUAN}

Di dalam novel diceritakan masalah kehidupan manusia dalam interaksinya dengan lingkungan sekitarnya (Salfia, 2017; Winusari, 2019). Pada saat berinteraksi itulah terjadi konflik antartokoh yang berperan dalam cerita tersebut (Asmida, 2020). Dari konflik tersebutlah selanjutnya akan menimbulkan pergolakan jiwa sehingga mengubah jalan tokoh (Anjeli, Syam, \& Seli, 2018).

Kepribadian tokoh dalam fiksi dengan kehidupan manusia dalam dunia nyata memiliki keterkaitan yang cukup erat (Fajriyah, Mulawarman, \& Rokhmansyah, 2017). Sebagaimana manusia pada umumnya, di dalam cerita novel, seorang tokoh akan memiliki kepribadian dan kebiasaan tertentu. Kita mungkin akan mengenal sosok tokoh dalam kehidupan nyata yang berwatak baik, buruk, penyabar, tempramen, bijaksana, dan lain-lain. Ternyata, hal tersebut juga dapat kita temukan di dalam cerita novel. Hal ini mengingatkan kita bahwa memang novel merupakan cerita refleksi kehidupan nyata yang dituangkan dalam sebuah tulisan (Rahayuningtyas, 2014).

Kepribadian tokoh dalam sebuah cerita tidak selalu dijelaskan secara langsung oleh pengarang cerita. Penjelasan mengenai kepribadian tokoh tersebut memerlukan sarana dan cara tertentu. Oleh karena itu, di sinilah letak kreativitas pengarang dalam membuat karakter melalui berbagai macam cara. Cara tersebut dapat melalui penjelasan langsung pengarang, gerak-gerik tokoh, jalan pemikiran tokoh, dialog tokoh dengan tokoh lain, dialog tokoh lain terhadap tokoh tersebut, dan tanggapan tokoh terhadap satu masalah yang dihadapi (Arifani, Munaris, \& Widodo, 2019; Isthifa, 2014; Milawasri, 2017; Miranda, Nazaruddin, \& Sunarti, 2019).

Dalam penelitian ini, penulis membahas mengenai psikologi tokoh yang memunculkan kepribadian dalam tokoh novel Pulang. Novel Pulang adalah sebuah novel yang diciptakan oleh Leila S. Chudori yang mendapatkan penghargaan Khatulistiwa Literary Award (Anugerah Sastra Khatulistiwa) pada tahun 2013 kategori prosa (Wulandari, 2019). Penghargaan ini diberikan karena novel Pulang dinilai memiliki kekuatan yang menggabungkan cuplikan-cuplikan peristiwa tentang kehidupan orang eksil (orang-orang Indonesia yang tidak bisa pulang ke tanah air karena situasi politik pada tahun 1965 secara paralel. Novel Pulang saat ini sudah diterjemahkan ke dalam bahasa Jerman, Perancis, Inggris, Belanda, dan Itali. Buku ini juga melengkapi koleksi buku Indonesia, sebagai tamu kehormatan, dalam ajang Frankfurt Book Fair bulan Agustus tahun 2015 (Anoprianti, 2018).

Novel Pulang berkisah tentang empat eksil politik Indonesia yang menjadi pendiri "Restoran Tanah Air" di Paris: Dimas Suryo, Nugroho Dewantoro, Risjaf, dan Tjahjadi Sukarna (Tjai Sin Soe). Keempatnya adalah wartawan-kecuali Tjai-pada Kantor Berita Nusantara sebelum Peristiwa 30 September 1965 terjadi.

Dimas Suryo, tokoh yang akan dikaji wataknya merupakan eksil politik yang serta tokoh sentral dalam novel ini. Dia dikisahkan sebagai seseorang yang senantiasa memendam harapan dan keinginan untuk pulang ke Indonesia, entah hidup atau mati. Sebab baginya "Indonesia" adalah rumah, kendati pemerintahnya (mungkin juga sebagian warganya) tidak menghendaki kehadirannya. 
Leila S Chudori menceritakan kehidupan berbagai tokoh dalam Pulang dengan sangat menarik dan detail. Yang perlu diingat, Dimas Suryo hanyalah wartawan yang dicurigai dekat dengan ideologi komunis, padahal mereka sama sekali bukan bagian dari PKI. Bayangkan sendiri nasib orang-orang yang benar-benar berhubungan dengan PKI.

Dalam penelitian ini, peneliti mengidentifikasi kepribadian tokoh dengan menggunakan pendekatan psikoanalisis Sigmund Freud. Dalam konsep analisis psikologi Sigmund Freud, manusia diyakini mempunyai semacam energi yang mendorongnya untuk bertingkah laku. Tingkah laku ini bersifat dinamis sesuai kondisi yang tengah terjadi (Wijaya \& Darmawan, 2019). Energi yang dimaksud oleh Freud tersebut terdiri atas Id, Ego, dan Superego. Id berfungsi sebagai energi yang memunculkan insting bertahan hidup dan mencari kepuasan atas dorongan nafsu yang muncul dalam diri manusia. Ego berfungsi secara rasional sebagai proses yang paling masuk akal untuk memuaskan dorongan Id. Superego berfungsi sebagai batasan-batasan moral yang memberikan konsep baik-buruk saat seseorang memuaskan dorongan Id-nya (Bertens, 2006; Helaluddin \& Syawal, 2018; Wiraatmaja, 2003).

Penggunaan teori psikoanalisis Freud dipilih mengingat setiap perbuatan manusia pasti didorong oleh gejolak batin sebelum seseorang melakukan atau memutuskan sesuatu. Objek yang akan dikaji dengan psikoanalisis ini adalah kepribadian tokoh dalam novel Pulang karya Leila S. Chudori yang menceritakan tentang kondisi Indonesia saat tragedi G-30S-PKI.

Penelitian terdahulu yang relevan dengan penelitian ini pernah dilakukan oleh Puji Lestari Budiningrum (2014), Gaby Rostanawa (2018), dan Melia Nuryanti \& Teti Sobari (2019). Budiningrum mengkaji Pulang dengan pendekatan psikoanalisis Sigmund Freud. Meskipun penelitian Budiyarti secara tema sama dengan penelitian ini, Budiyarti hanya menganalisis tokoh Dimas Suryo sebagai bahan kajian psikoanalisis. Sementara, penelitian ini mengkaji tiga tokoh sekaligus yaitu Dimas Suryo, Lintang Utara, dan Segara Alam sehingga kajian psikoanalisis pada novel Pulang lebih mendalam. Ada pun Gaby Rostanawa mengkaji psikologi sastra pada novel Pulang dengan teori Psikologi Humanistik Abraham Maslow yang tentu berbeda dengan psikoanalisis Freud. Terakhir, Nuryanti \& Teti Sobari menganalisis novel Pulang dengan pendekatan psikologis tanpa berpegang pada pisau analisis berdasarkan teori ahli sehingga penjelasannya masih menggantung.

\section{METODE}

Penelitian ini menggunakan metode kualitatif dengan menganalisis teks yang terdapat dalam novel yang dibuat oleh pengarang Leila S. Chudori yang berjudul Pulang yang diterbitkan oleh Gramedia dengan tebal 464 halaman. Data yang terkumpul dalam penelitian ini berbentuk kata-kata, bukan angka-angka sehingga proses deskripsi dan penjelasan cukup panjang dan detil. Hasil penelitian berisikan kutipan-kutipan yang diinterpretasikan dari isi novel untuk memberikan ilustrasi yang selanjutnya diinterpretasi oleh peneliti.

Teknik analisis data dalam penelitian ini bersifat analisis dengan cara mengidentifikasi data-data mengenai aspek psikologi tokoh dalam novel Pulang karya Leila S. Chudori. Analisis data dimulai dari mencari referensi, sumber-sumber tentang pengertian psikologi tokoh-tokoh dalam novel, membaca dan mengamati novel, hingga mengamati tingkah laku tokoh. Kemudian, hasil pengamatan terhadap novel tersebut diinterpretasikan berdasarkan teori psikonalisis Sigmund Freud yang terdiri dari id, ego, dan superego. Akhirnya, pada hasil 
dan pembahasan penelitian akan disajikan penggambaran konsep psikoanalisis dari tiga tokoh yaitu Dimas Suryo, Lintang Utara, dan Segara Alam berdasarkan pembagian id, ego, dan superego.

\section{HASIL DAN PEMBAHASAN}

Psikoanalisis Sigmund Freud mencakup aspek-aspek perwatakan (kepribadian) tokohtokoh dalam novel. Data-data temuan mengenai aspek-aspek perwatakan kepribadian tokoh dalam novel Pulang disajikan dalam penjelasan berikut:

\section{Dimas Suryo}

Dari tiga tokoh, Dimas Surya adalah tokoh yang tidak memiliki darah keturunan PKI. Hanya saja, beberapa kerabat Dimas berafiliasi dengan PKI dan banyak yang telah dieksekusi. Dimas berada pada posisi netral, tidak memihak PKI dan juga tidak memusuhi PKI. Namun, situasi politik menyebabkan posisi dimas yang abu-abu dianggap sebagai pro PKI.

Dari 4 episode dan 35 paragraf, aspek-aspek kepribadian yang mucul dalam tokoh Dimas Suryo adalah id, ego dan super ego.

\section{Kepribadian Id Dimas Suryo}

Kepribadian Id : Sifat seseorang yang selalu mencari kenikmatan. Kemunculan id muncul pada 11 paragraf. Untuk memperjelas informasi tersebut berikut disajikan contoh data tentang id.

1) Dimas Suryo yang dianggap memiliki keterlibatan dengan Lekra yang berafiliasi dengan PKI tetap bertahan tinggal di Prancis karena di Indonesia sedang terjadi perburuan besarbesar terhadap orang-orang yang terlibat PKI atau keluarga PKI atau rekan-rekan anggota PKI atau bahkan tetangga atau sahabat yang dianggap dekat dengan PKI diburu, ditahan, dan diinterogasi.

2) Ketika Dimas akan membuka surat kedua yang ditulis oleh Kenanga, puteri sulung Hananto, dia tak memiliki keberanian karena dianggap akan membuatnya semakin lumpuh.

3) Setelah menetap di Prancis, Dimas mengenal Vivienne, seorang mahasiswa Universitas Sorbonne yang kemudian menjadi kekasihnya. Ketika Dimas sedang berdiskusi dengan Vivienne, ada dorangan biologis yang terjadi secara spontan untuk mencium Vivienne agar dia berhenti menceracau cerita tentang demonstrasi di Paris 1968 (Pulang, hlm. 15).

4) Saat Vivienne mengajak Dimas mengelilingi bagian Paris, Dimas berpikir dirinya sebagai seorang pengelana. Hari-hari yang dijalaninya sebagai flaneur 'pengembara' pun menjadi lebih berwarna karena ditemani oleh Vivienne yang memiliki mata yang indah. Lalu, muncul perasaan Dimas untuk dapat memiliki Vivienne selama-lamanya (Pulang, hlm. 18).

5) Mengetahui bahwa Vivienne juga memiliki kesamaan dengannya, sebagai pengembara. Ada dorongan primitif dalam diri Dimas sebagai bentuk dorongan yang ada pada diri manusia yang menghendaki untuk segera dipenuhi atau dilaksanakan keinginan atau kebutuhanya. Hal ini tersebut merupakan aspek id dalam psikologi untuk "mencari kenikmatan" (Pulang, hlm. 25).

6) Dalam alam bawah sadarnya, Dimas berpikir kurang ajar untuk menjilat leher jenjang Vivienne karena melihatnya yang menggenakan $t$-shirt tanpa lengan dengan keringat yang 
membasahi leher jenjangnya meminum bir Alsace. Pikiran tersebut di dorong oleh aspek biologis yang secara spontan terjadi untuk "mencari kenikmatan" sebagai kewajaran dari psikologis laki-laki yang memiliki nafsu (Pulang, hlm 26).

7) Ketika mengolah bumbu di dapur, Dimas justru tak bisa menahan hasrat dirinya untuk bercinta dengan Surti. Hal tersebut merupakan dorongan dari alam bawah sadar yang berisi insting dan nafsu-nasfu yang tak kenal nilai untuk segara "mencari kenikmatan" yang secara psikologis merupakan aspek $i d$ dalam diri manusia (Pulang, hlm. 61).

8) Ketika kisah cinta Dimas pupus dengan Surti, dia selalu meniduri berbagai perempuan untuk mengatasi rasa patah hatinya. Sikap tersebut juga secara psikologis merupakan aspek id yang berupa dorongan alam bawah sadar yang berisi insting dan nafsu-nasfu yang tak kenal nilai, tetapi bukan untuk "mencari kenikmatan" melainkan untuk "menghindari ketidaknyamanan" (Pulang, hlm. 64).

9) Setelah menikah dengan Vivienne, Dimas dituntut bekerja untuk membantu Vivienne membiaya kehidupan mereka. Dimas pun bekerja di Kementerian Pertanian. Namun, karena merasa tidak nyaman dengan pekerjaannya, Dimas memutuskan untuk berhenti. Hal itu dilakukan akibat dari psikologis dirinya yang menolak dan berusaha untuk "menghindari ketidaknyamanan". Ini adalah bagian dari aspek id sebagai dorongan dalam diri manusia (Pulang, hlm. 88).

10) Dimas terus "menghindari ketidaknyamanan" dengan menyembunyikan hasil tes kesehatannya. Vivienne walaupun telah bercerai dengan Dimas tetap menaruh perhatian dengannya. Namun, desakan Vivienne agar Dimas jujur mengenai hasil tes kesehatannya gagal karena Dimas terus mengelak (Pulang, hlm. 270).

\section{Kepribadian Ego Dimas Suryo}

Kepribadian Ego : Sifat seseorang yang dapat memuaskan diri tanpa mengakibatkan kesulitan bagi dirinya sendiri. Kemunculan Ego muncul pada 15 paragraf. Untuk memperjelas informasi tersebut berikut disajikan contoh data tentang ego.

1) Dimas merasa memiliki kecocokan dengan Vivienne yang juga seorang pengembara. Selain itu, ketertarikan Dimas pada mata dan bibir Vivienne yang membuat Dimas ingin mendapatkan Vivienne. Hal tersebut merupakan dorongan psikologis yang memerlukan proses melalui "penalaran" sebagai bentuk dari ego (Pulang, hlm. 18-19).

2) Awalnya Dimas menutupi sejarah hidupnya sebagai korban politik Indonesia. Namun, setelah dia merasa Vivienne sudah memasuki seluruh hatinya, pori-porinya, dan jantungnya, maka Dimas melakukan "pengembalian keputusan" dengan merelakan Vivienne perlahan menguak tirai hitam sejarahnya. Hal tersebut merupakan bagian dari ego sebagai akibat pengaruh individu kepada dunia objek dari kenyataan dan menjalankan fungsinya berdasarkan prinsip kenyataan (Pulang, hlm. 21).

3) Dimas yang tak tahan dengan nafsu birahinya, justru akhirnya bersyukur kepada alam karena hal tersebut membuatnya dapat bercinta dengan Vivienne dan memuaskan nafsunya. "Pengembalian keputusan" tersebut secara teori psikologi sastra merupakan bagian dari ego karena timbul dari kebutuhan-kebutuhan organism yang membutuhkan pemuasan seksual (Pulang, hlm. 27).

4) Menurut Dimas, novel-novel yang dibahas Hananto itu berterminologi realisme sosial yang menjadi barang sakti untuk menjilat Pimpnan Redaksi yang sangat dekat dengan petinggi 
PKI. Hal tersebut merupakan bagian dari ego yang timbul karena dorongan psikologis yang memerlukan proses dalam pengaktualisasiaannya (Pulang, hlm. 31).

5) Dimas yang masih memiliki perasaan dengan Surti merasa heran karena menurut penalarannya, apabila dia sudah beristeri perempuan seindah dan semulia Surti, berarti dia telah memilih dan tak akan menyari perempuan lain lagi. "Penalaran" tersebut dalam teori psikologi merupakan bagian dari ego yang timbul dari manusia (Pulang, hlm. 39).

6) Aspek ego dalam diri Dimas juga kembali terlihat saat ketidakterimaan Dimas pada perilaku Hananto yang menganggap Surti adalah pendamping hidup dan dengan Marni dia merasakan nafsu kamu proletar yang bergelora, membuat Dimas marah dan membuat sebuah "penyelesaian masalah" untuk tidak mencampuri urusan Hananto. Hal tersebut disebabkan pada diri Dimas ada dorongan psikologis untuk menyelesaikan permasalahannya dengan Hananto (Pulang, hlm. 42).

7) Dalam perdebatan, Hananto merasa jengkel karena Dimas tak mau memihak baik pada ormas maupun partai. Selain itu, Hananto membahas mengenai kehidupan pribadi Dimas yang masih tertambat pada masa lalu. Namun, Dimas dengan "penalaran" menanggapi semua pernyataan Hananto tersebut dengan mempertanyakan paham-paham seperti sosialisme, komunisme, dan kapitalisme harus ditelan bulat-bulat tanpa mengkritisinya. Dalam teori psikologi, pemikiran Dimas itu merupakan bagian dari Ego yang timbul dari aspek psikologis yang memerlukan sebuah proses (Pulang, hlm. 43).

8) "Penalaran" Dimas yang merasa dirinya adalah sebuah kapal yang enggan berlabuh selama-lamanya. Akhirnya Surti yang menuntut Dimas menjalin hubungan yang lebih serius setelah percintaan mereka di dapur pun kecewa karena prinsip Dimas yang enggan menentukan pilihan. Prinsip tersebut didasari oleh kebutuhan-kebutuhan organisme yang memerlukan transaksi-transaksi yang sesuai dengan dunia kenyataan objektif (Pulang, hlm. 61).

9) Setelah pembicaraan undangan makan malam dengan keluarga Surti tak disetujui Dimas, membuat mereka sulit bertemu. Dimas sibuk dengan ujian akhir dan Surti selalu menghindar di kampus. Namun, akhirnya ada "pengembalian keputusan" yang diambil Dimas untuk menjalin hubungan yang lebih serius dengan Surti setelah wisuda. Hal tersebut merupakan bagian dari ego yang timbul akibat dorongan psikologis yang memerlukan proses (Pulang, hlm. 63).

10) Dimas menolak untuk berangkat ke Santiago, Cile menggantikan Hananto mengikuti konferensi International Organization of Journalists. Namun, setelah mendengar alasan Hananto untuk tidak berangkat, Dimas pun bersedia menggantikan Hananto. Hal tersebut menunjukan adanya ego dalam diri Dimas untuk "penyelesaian masalah" (Pulang, hlm. 69).

11) Langkah "penyelesaian masalah" yang dilakukan Dimas berikutnya setelah mereka mengetahui terjadi tragedi berdarah 30 September 1965 di Indonesia. Setelah tak bisa pulang ke tanah air, kemudian justru merantau hidup di Cina dalam perkampungan komunis di Desa Merah. Dimas yang merasa tak nyaman dengan kehidupan komunis di Cina, akhirnya memutuskan sebuah solusi untuk hidup di Paris bersama ketiga rekannya. (Pulang, hlm. 77). 
12) Dimas mulai menyesali tindakannya yang tidak berpendirian karena hal tersebut justru membuat keluarganya ditimpa kesulitan di Indonesia. Ibu dan adiknya terus diteror oleh perburuan dan pembantaian. Kesadaran itulah yang membuat sebuah "penalaran" di dalam diri Dimas yang di dorong oleh aspek psikologis yang timbul akibat adanya tekanan dan ketakutan yang luar biasa (Pulang, hlm. 80).

13) Mendengar kabar ibunya telah meninggal, Dimas begitu sangat terpukul sehingga mengurung diri dan memutuskan untuk pulang ke Indonesia walau di sana sedang dalam kondisi yang berbahaya. Ego "penyelesaian masalah" yang cenderung gegabah itu merupakan bentuk reaksi dalam diri Dimas yang timbul karena merasa memiliki kebutuhan dan keharusan untuk bertemu ibunya (Pulang, hlm. 84).

14) Dimas dikarunia seorang anak bernama Lintang Utara. Setelah beranjak remaja, terjadi perselisihan antara keduanya. Namun, setelah perselisihan di antara mereka meredah. Dimas berusaha untuk tidak bertengkar lagi oleh anaknya yang tidak membolehkannya merokok. Tindakan tersebut secara psikologis merupakan aspek ego karena diambil untuk "penyelesaian masalah" (Pulang, hlm. 230).

15) Ego terbentuk dengan diferensiasi dari id karena kontaknya dengan dunia luar. Dimas yang selalu berpikir bagaimana membangun humanitas di dalam masyarakat dengan organisasi, mulai menemukan jalan spritualisme melalui diskusinya dengan Amir yang taat beragama. Munculnya "penalaran" spiritual dalam diri Dimas merupakan bagian dari ego dalam teori psikologi (Pulang, hlm. 237).

16) Dimas yang sebenarnya terkena penyakit cirrhosis selalu menutup-nutupi penyakitnya. Dimas merasa gaya dokter dan suster itu lebih sering seperti penguasa. Dalam diri Dimas ada "penalaran" untuk menolak menggantungkan hidup-mati kepada dokter. Penalaran tersebut berangkat dari ego Dimas yang didorong oleh aspek psikologis (Pulang, hlm. 444445).

17) Diakhir hayatnya, Dimas menyerahkan "pengembalian keputusan" kepada Lintang untuk memilih pasangan hidupnya. Pengembalian keputusan tersebut didasari oleh beberapa hal yang menurut Dimas adalah langkah terbaik. Secara psikologis, tindakan tersebut menjadi jalan bagi Lintang untuk memilih (Pulang, hlm. 448).

Kepribadian Superego Dimas Suryo

Kepribadian Superego : Sifat seseorang yang mengejar kesempurnaan. Kemunculan Superego muncul pada 8 paragraf. Untuk memperjelas informasi tersebut berikut disajikan contoh data tentang superego.

1) Musim panas di Paris membuat Vivienne tidak pernah mengenakan bra. Hal itu membuat Dimas sangat risih karena selalu diserang oleh imanjinasi yang menantang birahinya. Dimas yang berasal dari Indonesia tentu memiliki nilai-nilai kesusilaan yang "merintangi impuls seksual" yang tercermin dalam psikologisnya yang mengedepankan superego ketimbang id (Pulang, hlm. 27).

2) Dimas seseorang yang mencintai belajar. Dia rajin dalam diskusi-diskusi pemikiran Karl Marx. Selain itu, Dimas juga merasa asyik dan nyaman berbincang dengan Amir tentang agama. Diskusi-diskusi seperti itu disukai oleh Dimas karena dia berusaha "mengejar kesempurnaan" untuk mencapai nilai-nilai tradisional serta cita-cita masyarakat. Hal tersebut didorong oleh superego dalam psikologis Dimas (Pulang, hlm. 29). 
3) Dimas merasa membutuhkan sepetak ruang kecil yang dikatakan Amir yang diberikan Allah kepada hamba-Nya. Penyerahan diri kepada Tuhan merupakan bagaian dari aspek superego karena berupa kesadaran "mengejar kesempurnaan" akan nilai-nilai keagamaan untuk ketentraman hidup manusia (Pulang, hlm. 80).

4) Dimas kembali menggunakan superego dalam dirinya untuk "mengejar kesempurnaan" ketika telah memiliki anak bernama Lintang Utara dari perkawaninannya dengan Vivienne. Adanya sistem kepribadian Dimas yang berisi nilai-nilai aturan yang bersifat evaluatif (menyangkut baik dan buruk) untuk berubah dalam hidupnya (Pulang, hlm. 86).

5) Ketika restoran Dimas didatangi polisi yang menuduh bahwa restoran Tanah Air sering digunakan untuk mengadakan diskusi-diskusi politik, Dimas yang tetap berusahan tenang dan santun dalam menanggapi polisi-polisi tersebut. Terlihat bahwa Dimas berusaha mengedepankan superego "mengejar moral" karena merasa nilai-nilai kesopanan akan membuat suasana menjadi lebih tenang (Pulang, hlm. 144).

6) Dimas yang meski selalu ditolak dalam pengajuan visa untuk masuk ke Indonesia, Dimas tak pernah menyerah. Hal tersebut merupakan bentuk superego karena nilai-nilai kecintaan pada tanah air telah membuat seluruh pencapaiannya adalah untuk dia bisa pulang ke tanah tempat dia dilahirkan (Pulang, hlm. 199).

7) Kecintaannya pada tanah air, membentuk cita-cita akhir hayat Dimas yang merindukan tempatnya berpulang. Rencana tersebut menjadi luhur karena jiwa nasionalisme yang muncul untuk "mengejar kesempurnaan" kesudahan hidup. Dimas dengan superegonya menanam nilai nasionalisme dalam dirinya dan mengatakan keinginannya untuk pulang ke rumahnya, di Karet (Pulang, hlm. 276).

8) Jiwa nasionalisme yang sudah begitu melakat dalam diri Dimas dan sulit untuk dilepas. Nilai-nilai ketuhanan dan kecintaan pada tanah air memperteguh psikologisnya, superego yang menuntunnya untuk "mengejar kesempurnaan" dengan mengatakannya untuk pulang ke Karet oleh Lintang (Pulang, hlm. 282).

9) Dalam usahanya untuk "mengejar kesempurnaan", Dimas mengatakan kemungkinan keberpulangannya kepada Lintang melalui surat. Dimas telah mempersiapkan kepulangannya karena dia telah mengisi sepetak kecil ruang di dalam hatinya untuk Allah (Pulang, hlm. 446).

10) Di akhir suratnya, Dimas memberi pesan kepada Lintang yang intinya adalah untuk "mengejar moral" dengan tidak menyeret-nyeret nasib dan perasaan orang. Oleh karena itu, Lintang harus berani menentukan pilihan agar jangan sampai hidupnya berantakan seperti ayahnya yang kurang bisa menentukan pilihan. Pesan tersebut keluar atas pertimbangan superego yang berisi seperti larangan dan perintah karena dalam pesan itu terkandung nilai-nilai moral dan cita-cita hidup manusia (Pulang, hlm. 448).

\section{Lintang Utara}

Berbeda dengan Dimas, Lintang Utara memiliki darah keturunan aktivis PKI. Hal tersebutlah yang membuatnya sering menjadi bahan gunjingan. Dari 5 episode dan 35 paragraf, aspek-aspek kepribadian yang muncul pada tokoh Lintang adalah id, ego dan super ego. 


\section{Kepribadian Id Lintang Utara}

Kepribadian Id : Sifat seseorang yang selalu mencari kenikmatan. Kemunculan id muncul pada 13 paragraf. Untuk memperjelas informasi tersebut berikut disajikan contoh data tentang id.

1) Ketertarikan Monsieur Dupont dengan sejarah Indonesia membuatnya meminta Lintang untuk membuat tugas akhirnya mengenai kehidupan bekas tahanan politik di Indonesia yang berarti menyangkut pula dengan sejarah kehidupan ayahnya. Lintang yang merasa sejarah itu adalah masa lalu yang selalu mengganggu tidurnya dan sudah dikubur dalam-dalam, mencoba "menghindari ketidaknyamanan" dengan berbohong menjawab pertanyaan dosennya itu. Psikologis Lintang yang menolak mengungkit kembali sejarah Indonesia membuat $i d$ dalam dirinya menjadi dorongan spontan untuk berbohong (Pulang, hlm. 137).

2) Lintang memiliki seorang kekasih bernama Nara, anak dari perkawinan Prancis dan Indonesia juga. Selama di Prancis, Nara selalu menjadi payung besar yang menaungi Lintang dalam berbagai permasalahannya. Mereka yang hidup dengan budaya Prancis yang memiliki kebebasan dalam pergaualan tentu seringkali terlibat dalam pemuasan seksualitas (Pulang, hlm. 158-167).

3) Lintang mengenalkan Nara kepada ayahnya, Dimas. Namun, ternyata ada ketidaksetujuan di dalam hati Dimas terhadap Nara yang lahir dari keluarga yang sangat mapan dan sedikit manja. Lintang yang merasa ayahnya telah menyerang Nara dengan pertanyaanpertanyaannya untuk menunjukan kelayakan Nara sebagai kekasih Lintang pun merasa kesal. Setelah pertemuan tersebut, Lintang menggugat ayahnya untuk "menghindari ketidaknyamanan" karena merasa tak mau bernasib seperti ayahnya (Pulang, hlm. 180).

4) Lintang yang memiliki rasa penasaran pada sebuah kotak yang berisi surat-surat yang dirahasiakan ayahnya pun mencoba membukanya. Dari surat-surat itu dia mengetahui betapa berdarahnya sejarah Indonesia dan kelamnya kehidupan ayahnya. Di akhir surat, Lintang merasa harus "menghindari ketidaknyamanan" dengan membaca surat-surat yang bisa menenangkan hatinya yang tersayat (Pulang, hlm. 250).

5) Lintang merasakan ada sesuatu yang aneh dalam dirinya, seperti sebuah halilintar yang biasa dikatakan oleh Mamannya, Vivienne yang jatuh cinta pada pandangan pertama oleh Dimas. Namun, Lintang berusaha "menghindari ketidaknyamanan" dengan selalu memikirkan Narayana yang telah menjadi payung besar yang melindungi hidupnya dari hujan dan badai cobaan. Id pada Lintang mencoba untuk tidak memedulikan halilintar yang mengenainya dari Alam (Pulang, hlm. 366).

6) Lintang yang dibantu Alam untuk menemui narasumber dalam film dokumenternya malah mengikuti jam wawancaranya dengan jadwal Alam. Ini disebabkan adanya perasaan yang dialami oleh Lintang. Namun, Lintang tetap berusaha "menghindari ketidaknyamanan" dengan menelepon Nara untuk tidak terjerumus oleh perasaannya (Pulang, hlm. 374).

7) Alam mencoba mengutarakan perasaannya kepada Lintang. Dia tak ingin nasib percintaannya seperti orangtua mereka, Dimas dan Surti yang kandas karena tak ada kepastian. Lintang yang merasa tak bisa menanggapi pernyataan Alam, akhirnya memilih diam untuk "menghindari ketidaknyamanan". Hal itu merupakan dorongan spontan dalam jiwanya (Pulang, hlm. 394). 
8) Lintang yang begitu senang melihat data-data untuk film dokumenternya tetap selamat pun akhirnya melupakan hal tabu dengan mencium Alam. Kesenangan Lintang telah secara spontan menjadi doroongan bagi Id dalam dirinya membuka hasrat "mencari kenikmatan" yang telah ditahan oleh mereka berdua (Pulang, hlm. 407).

9) Lintang memutuskan untuk "menghindari ketidaknyamanan" dengan selalu mengikuti kemana Alam pergi agar mereka tidak terpisah lagi. Secara psikologis sikap Lintang merupakan dorongan aspek biologis untuk merasa aman, senang, dan bahagia (Pulang, hlm. 421).

10) Lintang telah betul-betul terkena Le coup de foudre 'cinta pada pandangan pertama' dengan Alam. Awalnya kecanggungannya untuk menghindari dari rasa suka pada Alam dengan menelepon Nara, justru berbalik ketika dia telah menyadari cintanya, dia justru "menghindari ketidaknyamanan" ketika Nara menelepon saat berada di dekat Alam, dia hanya menjawab dengan mengulang-ulang saja sebagai reaksi kecanggungan. Hal tersebut bila dilihat dari teori psikologi merupakan aspek dari id karena terdapat dorongan primitif yang terjadi secara spontan untuk mencari aman (Pulang, hlm. 436).

Kepribadian Ego Lintang Utara

Kepribadian Ego: Sifat seseorang yang dapat memuaskan diri tanpa mengakibatkan kesulitan bagi dirinya sendiri. Kemunculan ego muncul pada 12 paragraf. Untuk memperjelas informasi tersebut berikut disajikan contoh data tentang ego.

1) Lintang merasa tak akan bisa mengunjungi Indonesia bersama ayahnya karena ayahnya adalah eksil politik yang telah diembargo oleh pemerintah. Secara psikologis "penalaran" Lintang merupakan bentuk ego karena adanya kesadaran pengaruh individu kepada dunia objek dari kenyataan dan menjalankan fungsinya berdasarkan prinsip kenyataan (Pulang, hlm. 146).

2) Lintang mendapat tawaran untuk datang dalam acara peringatan Hari Kartini di KBRI. Lintang yang awalnya tak percaya diri untuk ikut karena takut orang-orang akan membicarakannya sebagai anak dari Dimas Suryo, salah satu anggota PKI yang terusir dari Indonesia. Namun, Lintang melakukan "pengembalian keputusan" setelah Nara menawarkannya sebuah kebaya dan memberikannya sebuah ciuman. Ego pun timbul akibat adanya pengaruh yang didapat oleh Lintang melalui hal-hal yang dia sukai (Pulang, hlm. 158).

3) Lintang sudah berusaha membaca surat-surat Kartini dalam buku Habis Gelap Terbitlah Terang yang dia pikir akan menjadi bahasan diskusi dalam perayaan ini. Namun, nyatanya tidak demikian. Hal tersebut secara psikologi merupakan sebuah "penalaran" yang timbul atas ego dari kepribadian implementatif yaitu berupa kontak dengan dunia luar (Pulang, hlm. 162).

4) Lintang yang sempat menghentikan komunikasi dengan ayahnya karena memiliki kemarahan atas sikap Dimas terhadap Nara. Namun, setelah mengetahui kondisi ayahnya yang sakit Lintang mencoba untuk mengubur perseturuannya. Langkah "penyelesaian masalah" didasari atas ego yang muncul karena dorongan psikologis yang memerlukan sebuah solusi hidup (Pulang, hlm. 183).

5) Lintang selalu memendam pertanyaan-pertanyaan tentang hubungan segitiga antara Dimas, Surti, dan Hananto. Namun, dalam suatu kesempatan, Lintang memberanikan diri 
melakukan "penyelesaian masalah" dengan menanyakan perihal tersebut kepada ayahnya untuk melegakan hatinya. Ego membuat adanya dorongan psikologis yang menuntut Lintang melepas beban pemikirannya (Pulang, hlm. 277).

6) Di Indonesia terdapat larangan pemerintah untuk membaca buku-buku Karl Marx atau tafsirnya karena dianggap memiliki paham-paham komunisme. Hal tersebut membuat mahasiswa-mahasiswa di Indonesia justru menjadi penasaran dengan isinya. Dalam diskusi hal tersebut lintang mempunyai "penalaran" atas dasar egonya untuk memberikan sebuah kesadaran pada kenyataan objektif (Pulang, hlm. 371).

7) Seusai Lintang mewawancarai Surti, dia diantar pulang oleh Alam dengan taksi. Di dalam taksi, Alam terus menggenggam tangan Lintang. Lintang yang memiliki perasaan suka kepada Alam pun tak keberatan. Namun, di perjalanan, Lintang menerima telepon dari Nara, kekasihnya di Prancis. Dari hal itu, muncul "penalaran" dibenak Lintang. Penalaran tersebut didasari oleh ego yang mendapat pengaruh dari dalam dan luar dirinya (Pulang, hlm. 393).

8) Terjadi peristiwa penembakan mahasiswa di Trisakti. Lintang yang tak ingin kehilangan dokumentasi tentang kejadian ini pun merekam semua hal. Menurut "penalaran" Lintang tidak hanya orang-orang yang berbicara, tetapi benda-benda disekitarpun turut berbicara bahkan lebih jujur memberikan kesaksian. Ego lintang merasakan adanya penalaran pada tiap-tiap benda dan bernyawa (Pulang, hlm. 416).

9) Setelah Lintang melihat sendiri kejadian demi kejadian di Indonesia, dia menjadi merasa dikhianati karena saat sudah mulai mencintai Indonesia, tetapi peristiwa-peristiwa kekerasan terjadi di depan matanya. Rasa cinta itu menjadi "penalaran" atas dasar ego yang timbul dari dorongan psikologis Lintang (Pulang, hlm. 428).

10) Lintang telah menyelesaikan semua tugas wawancaranya. Dia merasa ingin pulang, Namun, muncul pertanyaan dalam benaknya, sebuah "penalaran" tentang tempat tinggal yang sesungguhnya. Sisi ego muncul dari dorongan psikologis yang menjadi sistem kepribadian yang bertindak sebagai pengaruh individu kepada dunia objek dari kenyataan dan menjalankan fungsinya berdasarkan prinsip kenyataan (Pulang, hlm. 438).

11) Alam mencoba menyadarkan Lintang bahwa rumahnya adalah Indonesia. Ketika orangorang meneriakkan reformasi, Lintang merasakan degup jantung yang lebih cepat dan darahnya berdesir. Hal itulah yang membuat Lintang yakin dalam "penyelesaian masalah" bahwa rumahnya adalah di Indonesia. Ego dalam dirinya menjadi dasar keyakinan itu (Pulang, hlm. 443).

12) Dimas yang akhirnya berpulang ke tanah airnya dan di makamkan di Karet. Lintang yang dari kecil biasa diajak Dimas berjalan-jalan di pemakaman Pere Lachaise kembali mengingat kenangan itu. Dalam "penalaran" ego Lintang membayangkan ada ayahnya tersenyum dari jauh, ayahnya begitu bahagia karena sudah pulang dan semua orang yang menyayanginya ada didekatnya (Pulang, hlm. 451).

Kepribadian Superego Lintang Utara

Kepribadian Superego : Sifat seseorang yang selalu mengejar kesempurnaan. Kemunculan superego muncul pada 11 paragraf. Untuk memperjelas informasi tersebut berikut disajikan contoh data tentang superego. 
1) Lintang lebih suka menghabiskan akhir pekan bersama keluarga Lefebvre karena Lintang melihat keluarga mereka sangat mesra dan rukun. Sikap Lintang tersebut di dorongan oleh keinginan "mengejar kesempurnaan" karena dia tak merasakan kemesraan dan kerukunan dalam keluarganya akibat perceraian ayah dan mamannya. Nilai-nilai kekeluargaan yang dirindukan Lintang, menjadikan superegonya mendorong untuk mengisi sesuatu yang hilang dari hidupnya (Pulang, hlm. 150).

2) Lintang akhirnya mulai membuka diri untuk mengakhiri perseturuannya dengan Dimas karena Lintang telah mengetahui beberapa hal tentang Indonesia dan sejarah ayahnya. Nilai-nilai superego untuk "mengejar moral" menjadi sistem kepribadian yang mampu menilai baik atau buruknya suatu tindakan (Pulang, hlm. 219).

3) Dalam tugas akhirnya, Lintang berusaha menggunakan superego dalam dirinya. Lintang mencoba "mengejar moral" untuk membuat sebuah film dokumenter yang bertujuan untuk mencari sisi manusiawi. Dia ingin menyorot nasib-nasib orang akibat konflik politik yang kemudian berakhir dengan banjir darah, korban jiwa yang begitu banyak, dan trauma politik berkepanjangan serta indoktrinasi luar biasa yang bisa melekat pada rakyat Indonesia (Pulang, hlm. 232).

4) Dimas sangat tahu anaknya, Lintang adalah anak yang baik dan mencintai orangtuanya. Oleh karena itu, dia tahu sebenarnya Lintang yang sudah dewasa tentu kalau dia ingin pergi kemana saja tak perlu lagi membicarakannya dengan orangtuanya. Namun, dengan superego dalam dirinya, dia ingin "mengejar moral" sebagai anak yang berbakti dengan orangtua (Pulang, hlm. 235).

5) Saat Lintang dan Dimas sedang berjalan-jalan mengelilingi Paris, Lintang mengungkapkan keinginannya kepada ayanya tepat di depan sungai Seine. Keinginan itu muncul atas dorongan superego untuk "mengejar kesempurnaan". Semua keinginankeinginan tersebut telah dipertimbangkan superego (Pulang, hlm. 274).

6) Setelah berada di Indonesia, salah satu narasumber dalam film dokumenter Lintang adalah Pak Prakosa, suami baru Rukmini, ibunya Bimo. Prakosa yang merupakan pensiunan tentara, menolak untuk berbicara. Namun, Lintang yang gagal mendapatkan informasi untuk tugas akhirnya tetap tidak marah, justru berlaku sopan-santun ketika Rukmini dengan memberikan isyarat untuk Lintang yang ditemani Alam dan Bimo untuk pergi. Secara teori psikologi, hal tersebut merupakan bentuk dari superego untuk "mengejar moral" (Pulang, hlm. 321).

7) Lintang merasa bersalah kepada keluarga Aji pun akhirnya memutuskan untuk meminta maaf. Hal tersebut dilakukan untuk "mengejar moral" atas pertimbangan superego dalam diri Lintang (Pulang, hlm. 362).

8) Setelah menyadari keegoisannya itu, Lintang meminta maaf kepada seluruh rekanrekannya. Lintang mencoba "mengejar moral" atas dasar superego sebagai sistem kepribadian yang berisi nilai-nilai aturan yang bersifat evaluatif (menyangkut baik dan buruk) (Pulang, hlm. 404).

9) Lintang juga merasa di Indonesia dia menjadi sungkan dan malu dalam hal-hal demikian. Superego menjadi pengatur dirinya untuk "mengejar moral" karena Superego menjadi pertimbangan bersikap (baik atau buruk) (Pulang, hlm. 422). 
10) Lintang yang malam itu menginap di kosan Alam mencoba "merintangi impuls seksual" yang diberikan Alam karena merasa Indonesia saat itu sedang masa berkabung. Penolakan tersebut merupakan pertimbangan dari superego yang berisi nilai-nilai aturan yang bersifat evaluatif (menyangkut baik dan buruk) (Pulang, hlm. 433).

\section{Segara Alam}

Tokoh Segara Alam adalah anak dari Hananto Prawiro. Ayah Segara Alam dieksekusi mati karena memiliki keterlibatan langsung dengan PKI. Dari 2 episode dan 22 paragraf, aspek-aspek kepribadian yang muncul pada diri Segara Alam adalah id, ego dan super ego. Kepribadian Id Segara Alam

Kepribadian Id : Sifat seseorang yang selalu mencari kenikmatan. Kemunculan id muncul pada 4 paragraf. Untuk memperjelas informasi tersebut berikut disajikan contoh data tentang id.

1) Sedari kecil Alam bersama temannya Bimo selalu mendapatkan hinaan dan perlakuan tidak mengenakan dari Denny, siswa di sekolahnya. Alam yang berusaha "menghindari ketidaknyamanan" dengan menghajar Denny ketika dia mengejek bapaknya sebagai pengkhianat negara. Sikap id tersebut timbul akibat dorongan biologis yang secara spontan dilakukan alam untuk melampiaskan emosinya (Pulang, hlm. 295).

2) Setelah menunjukkan kepada Lintang semua dokumen wawancaranya yang telah di back up, Lintang yang secara spontan mencium Alam karena kegirangannya. Alam yang terpancing hasratnya, akhirnya membalas ciuman Lintang dengan semangat yang menggebu. Terlihat bahwa Alam juga "mencari kenikmatan" yang sama. Hal tersebut terjadi karena adanya dorongan biologis yang secara spontan membuat nafsu birahi Alam memuncak (Pulang, hlm. 407).

3) Alam memang memiliki kebiasaan bercinta dengan perempuan. Jadi menurut Bimo, dia selalu memiliki kelebihan hormon. Terbukti, saat Lintang yang menginap di kosannya, Alam dengan sentuhan-sentuhannya kepada Lintang untuk mengajaknya bercinta walau Indonesia dalam keadaan berkabung (Pulang, hlm. 433).

4) Alam mencoba "menghindari ketidaknyamanan" karena merasa cemburu saat Lintang mendapat telepon dari Nara, kekasihnya di Prancis. Alam yang tak ingin terlihat cemburu akhirnya meminjam mobil Gilang untuk pergi dari ketidaknyamanannya itu (Pulang, hlm. 437).

\section{Kepribadian Ego Lintang Utara}

Kepribadian Ego : Sifat seseorang yang selalu mencari kenikmatan. Kemunculan ego muncul pada 10 paragraf. Untuk memperjelas informasi tersebut berikut disajikan contoh data tentang ego.

1) Alam yang merasa adanya malpraktek sejarah di Indonesia selalu mengkritisi setiap hal yang berkaitan dengan kenegaraan. "Penalaran" muncul dalam dirinya melalui ego yang mendorong psikologisnya untuk menyelesaikan diorama kebohongan itu (Pulang, hlm. 288).

2) Alam juga mengetahui bahwa beberapa sejarawan ada yang ingin menggali, mengulik, bahkan menggugat sejarah versi Orde Baru yang telah melakukan pembelokan sejarah dan amplikasi sana-sini agar beberapa tokoh terlihat sebagai pahlawan. "Penalaran" akan 
kekritisan Alam didasari ego yang menginginkan untuk adanya perubahan (Pulang, hlm. 290).

3) Alam tak pernah bisa merawat hubungannya dengan perempuan. Setelah mendapat nasehat dari kakaknya, Alam sedikit terbuka untuk "penyelesaian masalahnya" itu. Egonya menuntut untuk bisa menyelesaikan permasalahnya dengan membereskan kemarahan yang ada dalam dirinya (Pulang, hlm. 292).

4) Alam berangan, apabila ayahnya masih hidup, mungkin dia akan mempertanyakan sesuatu tentang Indonesia. Ego Alam menuntut sebuah "penalaran" tentang adanya malpraktek sejarah yang telah menindas bangsa Indonesia. Egonya terbentuk dengan diferensiasi dari Id karena kontaknya dengan dunia luar (Pulang, hlm. 293).

5) Alam yang merasa perbuatan Denny tidak bisa dibiarkan akhirnya mengambil langkah "penyelesaian masalah" dengan menghajar mereka. Sikap tersebut didasari oleh ego Alam yang terbentuk dengan diferensiasi dari Id karena kontaknya dengan dunia luar untuk menghindari ketidaknyamanan (Pulang, hlm. 297).

6) Ego timbul atas dorongan psikologis yang memerlukan proses dalam "penyelesaian masalah". Alam yang terus dikebiri oleh statusnya sebagai anak dari Hananto, salah seorang tahanan politik 30 September karena dianggap PKI. Dia mencoba menjawab semua pertanyaan-pertanyaan tentang 30 September dalam dirinya dengan melakukan berbagai hal (Pulang, hlm. 299).

7) Alam yang tak ingin mengecewakan Dimas, Ibunya, serta orang-orang yang dikenalnya mencintai Lintang akhirnya melakukan "penyelesaian masalah" dengan mengajak Lintang ke Monumen Pancasila Sakti untuk merekam banyak hal untuk tugas akhirnya. Tuntutantuntutan yang diterima Alamlah yang membuat egonya membantu Lintang menyusun tugas akhirnya (Pulang, hlm. 309).

8) Setelah terjadi kerusahan Mei 1998, jalan-jalan banyak diblokir. Alam mencoba mengatur semua temannya agar dapat pulang ke rumah masing-masing dengan aman. Langkah "penyelesaian masalah" yang diambil atas dasar egonya menjadikannya seperti diktator (Pulang, hlm. 425).

9) Alam mengetahui Lintang belum bisa memilih Nara atau dirinya atau apakah rumah sesungguhnya itu di Indonesia atau Prancis. "Penyelesaian masalah" itu diambil alam sebagai dorongan psikologis yang memerlukan proses karena memilih itu tak mudah untuk diambil oleh seseorang (Pulang, hlm. 442).

\section{Kepribadian Superego Lintang Utara}

Kepribadian Superego : Sifat seseorang yang selalu mengejar kesempurnaan. Kemunculan superego muncul pada 8 paragraf. Untuk memperjelas informasi tersebut berikut disajikan contoh data tentang superego.

1) Alam selalu merasa sinar mata bapaknya dapat membuatnya percaya hidup dengan kebaikan. Superego yang hadir dalam diri Alam untuk "mengejar moral" adalah nilai-nilai yang telah ditanamkan oleh keluarganya (Pulang, hlm. 292).

2) Alam tak pernah ingin menyulitkan orangtuanya. Sistem kepribadiannya yang berisi nilainilai aturan yang bersifat evaluatif (menyangkut baik dan buruk) dapat menyadarkan bahwa menyulitkan orangtua adalah dosa terbesar. Oleh karena itu, untuk "mengejar moral" Alam selalu menuruti ibu dan kakak-kakaknya (Pulang, hlm. 298). 
3) Dalam setiap bertindak Alam selalu mengedepankan "mengejar moral" agar tidak membuat ibunya bersedih karena kebandelannya. Alam dengan superegonya menuruti ibunya untuk menyelesaikan kuliahnya dengan baik di Fakultas Hukum, UI. Ingat-ingatan tentang ibunya itulah yang menjadi nilai-nilai yang evaluatif dalam cara bertindak Alam (Pulang, hlm. 299).

4) Alam memang memiliki cita-cita untuk menjadikan Indonesia lebih baik. Setelah menyelesaikan studinya, dia berusaha "mengejar kesempurnaan" itu untuk mendirikan lembaga swadaya masyarakat untuk membantu kelompok minoritas yang diperlakukan tidak adil. Superego dalam dirinya menuntunnya untuk menjalankan nilai-nilai tradisional dan cita-cita masyarakat yang adil, makmur, dan sentausa (Pulang, hlm. 300).

5) Ketika diperingatkan Bimo untuk tidak membawa Lintang ke ranjang, seperti perempuanperempuan lain, Alam pun mencoba "merintangi impuls seksual" tersebut dengan mengatakan tidak ingin membawa cewe cerdas ke tempat tidur karena akan rewel. Pemikiran tersebut menjadi benteng untuk tidak melanggar nilai-nilai susila dalam masyarakat. Di situlah superego dalam dirinya berfungsi sebagai pertimbangan akan keinginan-keinginan mencari kenikmatan (Pulang, hlm. 317).

6) Alam membantu Lintang untuk menyelesaikan tugas akhirnya. Kebetulan narasumber dalam film dokumenter Lintang adalah Pak Prakosa, suami baru Rukmini, ibunya Bimo. Prakosa yang merupakan pensiunan tentara, menolak untuk berbicara. Rukmini memberikan isyarat agar mereka pergi. Alam yang pemarah mencoba mengedepankan superego untuk "mengejar moral" dengan berperilaku sopan atas penolakan tersebut (Pulang, hlm. 321).

7) Alam terus memutar-mutar rokok yang dipegangnya. Lintang yang merasa tak enak akan hal itupun membuka kaca taksi dan mempersilakan Alam untuk merokok. Namun, ternyata dengan memutar-mutar rokok itu Alam berusaha "merintangi impuls seksualnya" yang gelisah sejak tadi ingin mencium Lintang. Superego membentengi Alam untuk tidak melakukan apa yang keinginan-keinginan id atau nafsunya mau (Pulang, hlm. 327).

8) Alam menyatakan keinginannya untuk memiliki Lintang dan mengakhiri pencariannya setelah berusia 33 tahun. Surti selalu meniginkan Alam untuk berkeluarga, ternyata Lintanglah yang menjadi pilihan Alam untuk "mengejar kesempurnaan" hidupnya. Keputusan itu keluar atas dasar superego sebagai penyeimbang id dengan mengaktualisasikan nilai-nilai moral dalam masyarakat (Pulang, hlm. 393).

Peneliti telah menganalisis tokoh-tokoh dalam novel Pulang karya Leila S. Chudori dengan pendekatan psikologi sastra. Diketahui bahwa dari tokoh-tokoh keutuhan analisis psikologi sastra: $i d$, ego, dan superego bisa didapatkan karena perannya yang menjadi sorotan dan mengusai tiap babak dalam penceritaan. Analisis watak yang mendalam baru dapat dilakukan jika tokoh dikemukakan secara detil dan lengkap dalam suatu cerita (Alvin, 2020; Forno, 2015; Santora, 2013). Keutuhan penggambaran dan penceritaan tokoh membuat analisis psikologi sastra pada tokoh-tokoh menjadi lebih lengkap, kompleks, dan koheren.

Tergambar jelas psikologi tokoh Dimas Suryo dengan segala problematikanya sebagai eksil politik Indonesia dan kepala rumah tangga dari Vivienne istrinya dan Lintang anak tunggalnya. Id yang muncul dari psikologis Dimas untuk mencari kenikmatan didasari oleh dorongan biologis yang secara spontan terjadi akibat adanya faktor-faktor yang mendukung perwujudan keinginan- 
keinginan tanpa dasar pertimbangan nilai-nilai (Juraman, 2017). Keinginan tersebut terepresentasi seperti: mencari kenikmatan dengan pasangan pranikah atau tanpa status; menghindari ketidaknyamanan sebagai eksil politik yang tak bisa untuk pulang dan keluarga yang mempertahankan kerukunannya. Ego dalam diri Dimas Suryo terbentuk dengan diferensiasi dari id karena kontaknya dengan dunia luar. Ego timbul karena kebutuhan-kebutuhan organisme yang memerlukan transaksi-transaksi yang sesuai dengan dunia kenyataan objektif (Hall, 2017). Superego dalam diri Dimas merupakan pertimbangan dan pengontrol akan keinginankeinginannya sebagai orang Indonesia yang dikenal dengan adat ketimurannya untuk membangun cinta, memperjuangkan mimpi pulang ke tanah airnya, dan mengisi ruang kosong untuk Tuhannya. Semua itu terurai dalam sikap merintangi impuls seksual, mengejar moral, dan mengejar kesempurnaan.

Selanjutnya, dari ketiga sifat kepribadian id, ego, superego pada diri Lintang Utara jelaslah bahwa Lintang Utara lebih banyak menunjukkan sifat id yaitu mengungkapkan tentang sifat seseorang yang selalu mecari kenikmatan dan menghindari ketidaknyamanan. Lintang Utara sebagai tokoh yang mengisi babak kedua dan pengurai permasalahan di babak ketiga memiliki peran yang sangat vital dalam pengakhiran konflik-konflik dalam cerita. Posisi tokoh yang rumit dan peluang-peluang yang didapatkan membuat Lintang mampu menjadi solusi-solusi dari permasalahan ayahnya sebagai eksil politik yang ingin pulang untuk dikuburkan di Karet dan permasalahan kisah cintanya yang pupus dengan Surti.

Sebagai anak yang lahir di Prancis tentu berkultur Prancis dengan gaya pergaulannya yang menuruti diri mencari kenikmatan tanpa bertentangan dengan aturan adat dan agama. Sikap Lintang untuk menghindari ketidaknyamanan pun untuk tidak terlibat dalam sejarah kelam ayahnya sebagai eksil politik Indonesia. Ego Lintang muncul atas dorongan psikologis yang memerlukan proses karena kehadirannya sebagai penyelesaian masalah: penalarannya yang cerdas, tajam, dan penuh pertimbangan mencirikan dia sebagai mahasiswa Universitas Sorbonne yang kritis dan punya latar belakang yang luar biasa; penyelesaian masalah yang diambil atas dasar pemikiran setelah adanya benturan atau kontak dengan dunia luar; pengembalian keputusannya didasari oleh benturan akan keinginan-keinginannya akan suatu hal (Suprapto, 2019). Superego dalam dirinya muncul karena sifat dasar yang tumbuh dalam keluarga yang berbudi baik, jadi impian dan sikap yang diambil untuk merintangi impuls seksual, mengejar moral, dan mengejar kesempurnaan merupakan pertimbangan dari nilai-nilai moral, kekeluargaan, dan cita-cita hidup masyarakat (Nindyasari, 2018).

Selanjutnya, ketiga sifat kepribadian id, ego dan superego pada tokoh Segara Alam, jelaslah bahwa Segara Alam lebih banyak menunjukkan sifat ego yaitu sifat seseorang yang dapat memuaskan diri tanpa mengakibatkan kesulitan bagi dirinya sendiri dan melaksanakan penalaran serta pemikiran. Segara Alam tokoh yang lahir dari perkawinan Surti dan Hananto menjadi tombak dalam penyelesaian permasalahan cerita. Seorang laki-laki yang keras, kritis, dan bercita-cita memperbaiki sejarah hidup Indonesia yang penuh pembelokan terbentuk dari pengalaman hidup yang keras, sehingga lebih banyak memunculkan sifat ego dalam dirinya (Subqi, 2016).

Sebagai tokoh pada babak ketiga dalam penceritaan, psikologi Alam dapat terekam, baik $i d$, ego, maupun superegonya. Id untuk mencari kenikmatan dalam dirinya merupakan tularan dari bapaknya yang gemar berpetualang cinta dengan perempuan dan memiliki nafsu 
seksual yang tinggi; sikapnya yang keras untuk menghindari ketidaknyamanan biasanya muncul untuk memegang teguh harga dirinya dari hinaan dan teror akibat keterlibatan bapaknya pada PKI yang dianggap tidak bersih diri dan bersih lingkungan. Ego yang muncul dari sikap penalaran, penyelesaian masalah, dan pengembalian keputusan merupakan dorongan dari emosi, pemikiran kritis, dan cita-cita terwujudnya keadilan di negerinya. Superego menjadi benteng dalam bersikap Alam kepada ibunya, kakaknya, dan kepada masyarakat (Ali, 2016). Selain nitu, superego Alam merintangi impuls seksual yang dilakukannya hanya semata menghindari kemungkinan buruk dan nilai ketaatan pada orang tua, mengejar moral yang dilakukannya karena ketulusan untuk berbuat baik dan bakti pada ibunya.

\section{KESIMPULAN}

Dari hasil yang didapat tersebut dapat dikatakan bahwa setiap tokoh memiliki karakteristik masing masing. Unsur Id, Ego, dan Superego akan selalu ada pada diri setiap orang. Yang membedakannya dengan orang lain hanyalah pada bagian manakah dari ketiga sifat tersebut yang paling menonjol. Tokoh Dimas Suryo yang lebih menonjolkan sifat ego merupakan tokoh yang berusaha mendapatkan kenyamanan sendiri tanpa merugikan orang lain di sekitarnya. Tokoh Lintang Utara yang menunjukkan dominasi sifat id merupakan tokoh yang lebih mencari kenyamanan dan menghindari hal-hal yang dianggap kurang memberikan ketenangan bagi dirinya. Sedangkan tokoh Segara Alam, sama seperti Dimas Suryo yang lebih menonjolkan sifat ego yang tidak ingin memberikan hal yang merugikan bagi orang lain.

\section{DAFTAR PUSTAKA}

Ali, M. (2016). Hakekat Kepribadian Dalam Psikologi Islam. Tabawiyah.

Alvin, F. (2020). Penguatan Karakter Dalam Novel Gawang Merah Putih Karya FX Rudy Gunawan. Universitas Andalas.

Anjeli, N., Syam, C., \& Seli, S. (2018). Analisis Konflik Tokoh Dalam Novel Puber Karya Rio Rinaldo. Jurnal Pendidikan Dan Pembelajaran Khatulistiwa, 8(3), 1-13.

Anoprianti, L. K. (2018). Bentuk Pemanipulasian Sejarah Di Era Orde Baru Dalam Novel Laut Bercerita Karya Laila S. Chudori. In Prosiding Seminar Nasional Bahasa dan Sastra Indonesia (SENASBASA).

Arifani, P. S., Munaris, M., \& Widodo, M. (2019). Deskripsi Fisik Tokoh dalam Novel Suti Karya Sapardi Djoko Damono. Jurnal Kata (Bahasa, Sastra, Dan Pembelajarannya), 7(1), 1-10.

Asmida, E. (2020). Tumpang Tindih Konflik Pada Struktur Naratif Novel Lelaki Harimau Karya Eka Kurniawan. Diglosia: Jurnal Kajian Bahasa, Sastra, Dan Pengajarannya. https://doi.org/10.30872/diglosia.v3i2.38

Bertens, K. (2006). Psikoanalisis Sigmund Freud. Jakarta: Gramedia Pustaka Utama.

Budiningrum, P. L. (2014). Kepribadian Tokoh Dan Nilai Pendidikan Novel Pulang Karya Leila S. Chudori (Suatu Tinjauan Psikologi Sastra). Universitas Sebelas Maret.

Fajriyah, K., Mulawarman, W. G., \& Rokhmansyah, A. (2017). Kepribadian Tokoh Utama Wanita Dalam Novel Alisya Karya Muhammad Makhdlori: Kajian Psikologi Sastra. Journal of Culture, Arts, Literature, and Linguistics (CaLLs). https://doi.org/10.30872/calls.v3i1.773

Forno, D. M. (2015). Penggambaran Karakter pada Tokoh Utama dalam Film "Maleficent ." 
Jurnal E-Komunikasi Program Studi Ilmu Komunikasi Universitas Kristen Petra.

Hall, C. S. (2017). Naluri Kekuasaan Sigmund Freud. Jakarta: Narasi.

Helaluddin, \& Syawal, S. (2018). Psikoanalisis Sigmund Freud dan Implikasinya dalam Pendidikan. Research Gate.

Isthifa, K. (2014). Analisis Tokoh Dan Penokohan Dalam Hikayat Muda Balia Karya Teuku Abdullah dan M. Nasir. Genta Mulia.

Juraman, S. (2017). Naluri Kekuasaan dalam Sigmund Freud. Jurnal Studi Komunikasi.

Milawasri, F. A. (2017). Analisis Karakter Tokoh Utama Wanita Dalam Cerpen Mendiang Karya SN Ratmana. Jurnal Bindo Sastra, 1(2), 87-94.

Miranda, N., Nazaruddin, K., \& Sunarti, I. (2019). Deskripsi Fisik Tokoh Novel Layar Terkembang Karya STA dan Belenggu Karya Arjmin Pane. Jurnal Kata (Bahasa, Sastra, Dan Pembelajarannya), 7(2).

Nidyansari, D. A. (2018). Ketidakharmonisan Komunikasi Dalam Keluarga Pada Pembentukan Pribadi Anak (Pendekatan Humanistik). Jurnal Riset Komunikasi. https://doi.org/10.24329/jurkom.v1i2.39

Nuryanti, M., \& Sobari, T. (2019). Analisis Kajian Psikologi Sastra Pada Novel "Pulang" Karya Leila S. Chudori. Parole (Jurnal Pendidikan Bahasa Dan Sastra Indonesia), 2(4), 501-506.

Rahayuningtyas, P. (2014). Kajian Mimesis Dalam Novel Noruwei No Mori. Diglossia: Jurnal Kajian Ilmiah Kebahasaan Dan Kesusastraan, 6(1).

Rostanawa, G. (2018). Hirarki Kebutuhan Tokoh Utama dalam Novel Pulang dan Laut Bercerita Karya Leila S. Chudori (Kajian Psikologi Humanistik Abraham Maslow). ELite Journal: International Journal of Education, Language, and Literature.

Salfia, N. (2017). Nilai moral dalam novel $5 \mathrm{~cm}$ karya Donny Dhirgantoro. Jurnal Humanika. Santora, U. (2013). Perjuangan Hidup dan Kemandirian Tokoh Utama Dalam Novel Padang Bulan Karya Andrea Hirata: Sebuah Tinjauan Psikologi Sastra. Suluk Indo, 2(1), 244255.

Subqi, I. (2016). Pola Komunikasi Keagamaan Dalam Membentuk Kepribadian Anak. INJECT (Interdisciplinary Journal of Communication). https://doi.org/10.18326/inject.v1i2.648

Suprapto, S. (2019). Kepribadian Tokoh Dalam Novel Jalan Tak Ada Ujung Karya Muchtar Lubis Kajian Psikoanalisis Sigmund Freud. Metafora, 5(1), 165-180.

Wijaya, H., \& Darmawan, I. P. A. (2019). Optimalisasi Superego dalam Teori Psikoanalisis Sigmund Freud untuk Pendidikan Karakter.

Winusari, N. N. (2019). Struktur Naratif Novel Bumi Manusia Karya Pramoedya Ananta Toer: Sebuah Tinjauan Sosiologi Sastra. Jurnal Pendidikan Dan Pembelajaran Bahasa Indonesia, 7(2), 34-42.

Wiraatmaja, S. (2003). Pengantar Psikologi Umum. Ungaran: STT Simpson.

Wulandari, R. (2019). Imagining Home in Diaspora in Leila S. Chudori's Pulang (Home). Journal of Cultural, Literary, and Linguistic Studies, 3(2), 37-40. 